\title{
STATUS PEMBERIAN ASI EKSKLUSIF PADA BALITA STUNTING
}

\author{
Exclusive Breastfeeding Status In Children With Stunting
}

\author{
Masta Hutasoit \\ Prodi Keperawatan, Fakultas Kesehatan, Universitas Jenderal Achmad Yani Yogyakarta, DIY, \\ Indonesia \\ Korespondensi: hutasoitmasta@gmail.com
}

\begin{abstract}
ABSTRAK
Kasus stunting masih tinggi di Indonesia setara dengan 30,2\% dari seluruh balita di Indonesia. Disebut stunting atau pendek apabila hasil pengukuran tinggi badan atau panjang badan anak dihubungkan dengan umur $(\mathrm{TB} / \mathrm{U}$, atau $\mathrm{PB} / \mathrm{U})$ dengan nilai $Z$ - Score $<-2$, berdasarkan standar World Health Organization. Meskipun telah banyak usaha yang dilakukan untuk menekan angka stunting, tapi kenyataanya stunting masih tinggi. ASI eksklusif menjadi salah satu factor penyabab stunting. Masih banyak balita yang tidak diberikan ASI eksklusif selama 6 bulan pertama kehidupan, sehingga menyebabkan anak menjadi kurang gizi. Kekurangan gizi dalam waktu yang sangat lama diyakini menjadi penyebab stunting. Tujuan penelitian ini adalah untuk mengetahuan gambaran status pemberian ASI eksklusif pada balita stunting di Kabupaten Kulon Progo. Design penelitian dengan menggunakan deskriptif, data anak balita stunting diperoleh dari Puskesmas selanjutnya dilakukan home visit untuk dilakukan pengukuran antropometri, dan orangtua responden diminta untuk mengisis kuesioner tentang status pemberian ASI eksklusif. Responden pada penelitian ini sebanyak 100 anak balita usia 25 tahun yang mengalami stunting (data puskesmas). Hasil penelitian diperoleh bahwa terdapat $52 \%$ balita stunting yang memiliki status pemberian ASI eksklusif dalam kategori "terpenuhi" dan ada $42 \%$ balita stunting tidak diberikan ASI eksklusif ("tidak terpenuhi").
\end{abstract}

Kata Kunci: Balita, Stunting, ASI Eksklusif

\begin{abstract}
Stunting are still high in Indonesia, equivalent to $30.2 \%$ of all children under five in Indonesia. Stunting or short if the results of measurements of height or length of the child's body are associated with age (TB / U, or PB / U) with a Z-Score <-2, based on World Health Organization standards. Although many attempts have been made to reduce the number of stunting, but the fact is that stunting is still high. Exclusive breastfeeding is one of the factors causing stunting. There are still many children under five who are not exclusively breastfed during the first 6 months of life, causing children to become malnourished. Malnutrition for a very long time is believed to be the cause of stunting. .The purpose of this study was to explore the status of exclusive breastfeeding for stunting children under five in Kulon Progo Regency. Design research using descriptive, stunting data obtained from the Puskesmas then a home visit was conducted to conduct anthropometric measurements, and the respondent's parents were asked to complete a questionnaire about the status of exclusive breastfeeding. Respondents in this study were 100 children with aged 2-5 years who were stunted (primary health care data). The results showed that there were 52\% stunting children who had exclusive breastfeeding status in the "fulfilled" category and $42 \%$ of stunting toddlers were not given exclusive breastfeeding. The description of the status of exclusive breastfeeding for stunting children in Kulon Progo Regency was more in the category fulfilled by 52\%. The next researcher is expected to be able to examine other factors besides visit and exclusive breastfeeding factors in stunting toddlers.
\end{abstract}

Keyword: children under five, stunting, exclusive breastfeeding 


\section{PENDAHULUAN}

Stunting dalam bahasa awam dikenal dengan istilah pendek, merupakan kondisi gagal pertumbuhan pada anak (pertumbuhan tubuh dan otak) akibat kekurangan gizi dalam waktu yang lama. Stunting memiliki nilai $Z$ - Score $<-2$ standar deviasi (SD) berdasarkan standar World Health Organization (World Health Organization, 2018).

Sekitar 150,8 juta balita di dunia mengalami stunting, dimana lebih dari setengah balita stunting di dunia berasal dari ASIA (55\%) sedangkan lebih dari sepertiganya (39\%) tinggal di Afrika (Kementerian Kesehatan Republik Indonesia Direktorat, 2018). Prevalensi stunting menurut Badan Penelitian dan Pengembangan Kesehatan (2018), secara nasional pada tahun 2018 sejumlah 30,2\% yang berarti terjadi penurunan dibandingkan tahun 2013 (37,2\%) dan 2007 $(36,8 \%)$. Sementara itu, angka stunting di DIY tahun 2017 mengalami penurunan dari tahun 2016 yaitu sebesar $14,36 \%$ dan kembali turun menjadi $13,86 \%$ pada tahun 2017, dimana Gunung Kidul menempati urutan peratama dengan jumlah 20,60\% dan disusul Kulon Progo yang menempati urutan ke dua dengan kejadian stunting terbanyak yaitu mencapai 16,38\% (Dinas Kesehatan Daerah Istimewa Yogyakarta, 2017).

Balita yang mengalami stunting akan memiliki tingkat kecerdasan tidak maksimal, selain itu anak juga lebih rentan terhadap berbagai penyakit dan di masa depan dapat beresiko terjadinya penurunan tingkat produktivitas. Pada akhirnya secara luas stunting dapat menghambat pertumbuhan ekonomi dan meningkatkan kemiskinan (Mitra, 2015).

ASI merupakan nutrisi atau makanan terbaik bagi bayi karena mengandung zat gizi yang sangat sesuai dengan kebutuhan bayi dan mengandung zat perlindungan terhadap berbagai penyakit (Fahriani, Rohsiswatmo, \& Hendarto, 2014). ASI adalah merupakan sumber gizi utama bagi bayi yang belum dapat mencerna makanan padat (Kodrat, 2010). ASI kaya akan sarisari makanan yang mempercepat pertumbuhan sel-sel otak dan perkembangan sistem saraf. Meskipun sangat kaya akan zat gizi, ASI sangat mudah dicerna oleh sistem pencernaan bayi yang masih rentan (Marmi, 2012).

World Health Organization (WHO) menganjurkan pemberian ASI Eksklusif ini dapat mengurangi tingkat kematian pada bayi seperti diare, mengingat bahwa belum sempurnanya sistem pencernaan bayi yang berada di bawah enam bulan (Eveline PN \& Djamaludin, 2010). Unsur gizi ini menjadi pengaruh yang dominan dalam pertumbuhan anak terutama pada saat awal kehidupannya sampai umur 12 bulan. Nutrisi yang dibutuhkan oleh bayi hanya dapat dipenuhi dengan pemberian ASI (Fitri, Chundrayetti, \& Semiarty, 2014). Pemberian ASI diyakini menjadi salah satu masalah mendasar dari bayi kurang gizi, sebagaimana dikutip dari UNICEF mencatat bahwa $37 \%$ dari anak-anak Indonesia bertubuh kerdil, Indonesia menempati urutan ke lima terbesar dengan jumlah anak yang pertumbuhan terhambat di seluruh dunia (Unicef South Asia, 2017).

Hasil studi pendahuluan yang dilakukan pada tanggal 2 Maret 2019 di Puskesmas Kalibawang, di peroleh data pada tahun 2018 jumlah balita stunting usia 1-5 tahun sebanyak 310 balita dan petugas Puskesmas kalibawang melaporkan bahwa penyebab stunting paling banyak yaitu BBLR, MP-ASI kurang, ibu anemia, ibu KEK, dan ibu tidak teratur mengkonsumsi tablet Fe. Tujuan dari penelitian ini adalah untuk melihat gambaran status pemberian ASI eksklusif pada balita yang stunting di wilayah kerja Puskemas Kalibawang Kabupaten Kulon progo.

\section{TUJUAN PENELITIAN}

Tujuan penelitian ini adalah untuk mengetahui gambaran status pemberian ASI eksklusif pada balita stunting di Kulon Progo Yogyakarta

\section{METODE PENELITIAN}

Desain

Penelitian ini merupakan penelitian kuantitatif non eksperimental dengan jenis penelitian deskriptif analitik.

Populasi dan Sampel 
Populasi dalam penelitian ini adalah balita stunting dari empat Desa di Kecamatan Kalibawang yang berjumlah 310 balita stunting. Teknik pengambilan sampling adalah dengan purposive sampling. Sampel pada penelitian ini berjumlah 100 responden yaitu balita yang mengalami stunting.

\section{Tempat dan Waktu Penelitian}

Lokasi pengambilan data dilakukan di empat desa di wilayah kerja Puskesmas Kalibawang Kulon Progo Yogyakarta. Penelitian dilakukan selama 24 minggu>

\section{Instrumen dan Prosedur Pengukuran}

Data didapatkan dari Puskesmas

Kalibawang Kulon Progo Yogyakarta. Pengambilan data dilakukan dari rumah ke rumah (home visit) memberikan kuesioner pada ibu tentang kelengkapan status pemberian ASI eksklusif, setelah itu dilakukan pengukuran berat badan (BB) dan tinggi badan (TB) pada responden. Alat pengumpulan data dengan kuesioner yang sudah diuji validitas sebelumnya. Lokasi penelitian dilakukan di Wilayah Kerja Puskesmas Kalibawang Kabupaten Kulon Progo pada bulan April 2019 - Oktober 2019.

\section{Analisa Data}

Analisa data yang digunakan adalah analisa univariate untuk melihat gambaran status pemberian ASI eksklusif pada balita stunting. analisia univariat digunakan untuk mendapatkan gambaran karektristik masing-masing dari variabel penelitian dengan menyajikan distribusi, frekuensi dan presentase setiap variabel. Hasil penelitian disajikan dalam bentuk tabel distribusi frekuensi.

\section{HASIL PENELITIAN}

Hasil disajikan dalam tabel berikut ini:

Tabel 1

Distribusi Frekuensi Responden Berdasarkan Jenis Kelamin, Kelompok Usia, ASI Eksklusif dan Kejadian Stunting $(n=100)$

\begin{tabular}{ccc}
\hline $\begin{array}{c}\text { Karakteristik } \\
\text { Responden }\end{array}$ & Frekuensi & $\begin{array}{c}\text { Persentase } \\
(\%)\end{array}$ \\
\hline
\end{tabular}

\begin{tabular}{lll}
\hline Jenis Kelamin & & \\
\hline \multicolumn{1}{l}{ Laki-laki } & 48 & 48 \\
Perempuan & 52 & 52 \\
\hline Kelompok usia & & \\
\hline $24-36$ bulan & 45 & 45 \\
\hline $37-48$ bulan & 39 & 39 \\
\hline $49-60$ bulan & 16 & 16 \\
\hline ASI Eksklusif & & \\
\hline$\quad$ Terpenuhi & 58 & 58 \\
\hline$\quad$ Tidak Terpenuhi & 42 & 42 \\
\hline Kejadian Stunting & & \\
\hline$\quad$ Stunting & 69 & 69 \\
\hline$\quad$ Sangat Stunting & 31 & 31 \\
\hline Jumlah & $\mathbf{1 0 0}$ & $\mathbf{1 0 0}$ \\
\hline
\end{tabular}

Hasil analisa pada table 1 menunjukkan bahwa sebagian besar responden berjenis kelamin perempuan $(52 \%)$. Kategori usia responden paling banyak pada rentang usia 24-36 bulan sebanyak 45\%. Pemberian ASI eksklusif paling banyak kategori terpenuhi sebesar $54.3 \%$ dan responden paling banyak kategori klasifikasi stunting sebesar 69\%.

\section{Tabel 2}

Distribusi Frekuensi Orang Tua Responden Kelompok Usia, Pekerjaan, Paritas, dan pendapatan keluarga $(\mathrm{n}=100)$

\begin{tabular}{|c|c|c|}
\hline $\begin{array}{l}\text { Karakteristik } \\
\text { Responden }\end{array}$ & Frekuensi & $\begin{array}{l}\text { Persentase } \\
(\%)\end{array}$ \\
\hline \multicolumn{3}{|l|}{ Usia } \\
\hline 25-35 tahun & 67 & 67 \\
\hline$>35$ tahun & 33 & 33 \\
\hline \multicolumn{3}{|l|}{ Pekerjaan } \\
\hline $\begin{array}{cc}\text { Ibu } & \text { Rumah } \\
\text { Tangga } & \end{array}$ & 78 & 78 \\
\hline $\begin{array}{l}\text { Swasta, buruh, } \\
\text { Tani, dan lain- } \\
\text { lain }\end{array}$ & 22 & 22 \\
\hline \multicolumn{3}{|l|}{ Paritas } \\
\hline Anak 1 & 18 & 18 \\
\hline Anak 2 & 55 & 55 \\
\hline Anak $\geq 3$ & 27 & 27 \\
\hline \multicolumn{3}{|l|}{$\begin{array}{l}\text { Pendapatan } \\
\text { Keluarga }\end{array}$} \\
\hline$>$ UMR & 35 & 35 \\
\hline$<$ UMR & 75 & 75 \\
\hline Jumlah & 100 & 100 \\
\hline
\end{tabular}

Pada tabel 2 digambarkan bahwa usia ibu lebih banyak masuk kategori usia 25-35 tahun sebesar $67 \%$. Karakteristik pekerjaan 
ibu responden mayoritas ibu rumah tangga sebesar 78\%. Kategori Paritas, sebagian besar ibu memiliki 2 anak sebesar 55\%. Pendapatan keluarga paling banyak dibawah upah minimum regional (UMR) sebesar 75\%, adapun upah minimum regional adalah sebesar Rp. 1.400.000,(satu juta empat ratus ribu rupiah).

\section{PEMBAHASAN}

Hasil penelitian yang dilakukan Puskesmas Kalibawang dari 100 responden yang stunting diperoleh kategori stunting sebesar $69 \%$, dan sangat stunting 31\%. Hasil penelitian ini didapatkan sebagian besar pemberian ASI eksklusif pada balita dalam kategori "terpenuhi" sebesar 58\%, dan yang tidak terpenuhi sebesar $42 \%$, selisih hanya $16 \%$. Berbeda dengan penelitian di Manado oleh Pangalila, Punuh dan Kapantow (2019) bahwa pemberian ASI eksklusif hanya 30\% sementara balita yang tidak diberi ASI eksklusif sebesar $66,7 \%$.

ASI eksklusif artinya pemberian ASI saja tanpa makanan atau minuman yang lain. ASI Eksklusif diberikan selama 6 bulan pertama hanya ASI dan kemudian dilanjutkan selama 2 tahun dan diberikan juga makanan pendamping ASI (MPASI). Keuntungan pemberian ASI eksklusif adalah menghindari anak dari kurang gizi (malnutrisi), memaksimalkan kekebalan tubuh anak sehingga terhindar dari berbagai jenis penyakit, dan mencegah kematian pada bayi (Unicef South Asia, 2017). Beberapa penelitian menunjukkan bahwa pemberian ASI esklsklusif dapat mencegah stunting pada balita. Hasill penelitian di Banda Aceh menyimpulkan bahwa kejadian stunting disebabkan oleh pemberian ASI yang tidak eksklusif sebesar 4 kali $(p=0,002$ dengan OR 3,4). Penelitian lain menyebutkan bahwa bayi yang tidak diberikan ASI eksklusif memiliki resiko stunting sebanyak $16,5 \%$. Hal ini berkaitan dengan bayi yang tidak ASI eksklusif memiliki resiko penyakit infeksi seperti diare karena diberikan makanan selain ASI sebelum usia 6 bulan. Bayi yang terkena infeksi cenderung memiliki nafsu makan yang cenderung turun, dan penyerapan zat gizi yang tidak maksimal sehingga tidak mencukupi untuk pertumbuhan (Lestari, Margawati, \& Rahfiludin, 2014).

ASI atau sering disebut Air Susu Ibu adalah makanan yang paling baik untuk bayi, praktis dan murah. ASI diketahui memiliki semua komponen yang dibutuhkan oleh tubuh bayi termasuk zat gizi dan cairan untuk memenuhi kebutuhan bayi sebelum usia 6 bulan. Setelah usia 6 bulan bayi harus diberikan makanan tambahan selain ASI untuk memenuhi kebutuhan anak. Kolostrum memiliki lebih banyak zat antibody berwarna kuning dan jenis ASI yang keluar pertama kali. Setelah kolostrum ada ASI masa peralihan dan ASI mature (Walyani, 2015).

Faktor pengetahuan ibu turut mempengaruhi sukses tidaknya seorang ibu dalam memberikan ASI eksklusif. Seorang ibu yang memiliki pemahaman yang bagus tentang manfaat ASI eksklusif akan memiliki perilaku yang baik dalam pemberian ASI eksklusif. Faktor lain juga turut mempengaruhi seperti norma sosial, pekerjaan ibu dan pengalaman menyusui sebelumnya (Emma et al., 2015). Ketidaksuksesan ibu dalam pemberian ASI eksklusif dapat menyebabkan stunting. Selain itu dampak jangka panjang anak bisa mengalami kecerdasan yang kurang dibanding teman-teman seusianya (Kementerian Desa, Pembangunan Daerah Tertinggal, 2018; UNICEF South Asia, 2017).

Temuan lain dalam penelitian ini menunjukkan bahwa banyak balita yang tidak mendapatkan ASI Eksklusif pada usia 0-6 bulan, dengan hasil wawancara didapatkan bahwa menurut ibu, ASI tidak keluar dan ada beberapa ibu yang menderita Anemia, sehingga tidak boleh memberikan ASI nya kepada anak. Berdasarkan penelitian (Aridiyah, Rohmawati, \& Ririanty, 2015), menyatakan bahwa bahwa status menyusui juga merupakan faktor risiko terhadap kejadian stunting, rendahnya pemberian ASI ekslusif menjadi salah satu pemicu terjadinya stunting pada anak balita yang disebabkan oleh kejadian masa lalu dan akan berdampak terhadap masa depan anak balita, sebaliknya pemberian ASI yang baik oleh ibu akan membantu menjaga keseimbangan gizi anak 
sehingga tercapai pertumbuhan anak yang normal. Penelitian yang dilakukan oleh Aini, Nugraheni, \& Pradigdo (2018), bahwa 93,4\% balita stunting di Kabupaten Blora tidak mendapat ASI eksklusif dan bahkan mendapat MP-ASI terlalu dini sebelum 6 bulan. Itu sebabnya disamping stunting balita rawan menderita infeksi seperti diare dan pneumonia, serta terganggunya pertumbuhan fisik karena proses absorbsi nutrisi karena usus bayi yang belum siap mencerna selain ASI.

Pada penelitian ini sebagian besar $73 \%$ pendapatan keluarga balita stunting berada di bawah upah minimum Kabupaten Kulon Progo yaitu kurang dari $\mathrm{Rp}$ 1.450.000. Penelitian ini sejalan dengan penelitian yang dilakukan oleh Illahi (2017) bahwa sebagian besar $54,8 \%$ pendapatan keluarga balita berada di bawah upah minimum Kabupaten Bangkalan yaitu kurang dari $\mathrm{Rp}$ 1.414.000. Pendapatan merupakan salah satu indikator yang menentukan status ekonomi. Menurut Adriani \& Wirjatmadi (2012) daya beli keluarga dipengaruhi oleh besarnya pendapatan dalam menentukan jenis pangan yang akan dibeli. Semakin besar pendapatan keluarga maka akses untuk makanan bergizi semakin baik, dan sebaliknya jika pendapatan keluarga di bawah UMR maka akses untuk makanan bergizi menjadi kurang. Hal itu merupakan salah satu penyebab stunting pada balita. Dengan pendapatan yang tinggi dapat dimungkinkan terpenuhinya kebutuhan makanan seluruh anggota keluarga. Namun sebaliknya tingkat pendapatan keluarga yang rendah mengakibatkan rendahnya daya beli pangan rumah tangga yang menyebabkan minimnya ketersediaan nutrisi pada balita.

Pendapatan berkaitan juga dengan pekerjaan. Jenis pekerjaan yang paling banyak di wilayah kerja Puskesmas Kalibawang adalah bertani dan buruh tani. Pekerjaan bertani merupakan pekerjaan yang setiap bulan memiliki penghasilan yang tidak pasti atau tidak menentu. Ibu balita mayoritas hanya ibu rumah tangga yang tidak memiliki penghasilan. Artinya keluarga hanya mengandalkan penghasilan dari kepala keluarga (suami). Berbeda dengan penelitian Aini et al. (2018), bahwa mayoritas pekerjaan ibu adalah tidak bekerja (ibu rumah tangga), namun diketahui tidak ada hubungan antara pekerjaan ibu dengan kejadian stunting ditunjukkan dengan nilai p-value 0,892 . Pola asuh anak yang kurang baik tidak selalu disebabkan karena pekerjaan ibu tetapi bisa juga dengan kurangnya pengetahuan ibu tentang pentingnya gizi yang baik untuk pertumbuhan balita.

Menurut penelitian Aridiyah et al. (2015), bahwa balita stunting $100 \%$ berasal dari keluarga yang memiliki pendapatan rendah di wilayah desa, sementara wilayah kota sebesar 93,3\%. Penelitian lain yang dilakukan di Sumatera bahwa terdapat hubungan yang signifikan diantara pendapatan keluarga dengan kejadian stunting pada balita. Balita dari keluarga yang berpendapatan rendah memiliki 1,29 kali lebih tinggi mengalami stunting dibandingkan dengan keluarga yang memiliki pendapatan tinggi (Oktarina \& Sudiarti, 2013).

Intervensi untuk mengurangi stunting ditujukan kepada anak dalam 1000 hari pertama kehidupan (HPK) berkontribusi terhadap penurunan stunting sebnayak $30 \%$. Inetrvensi tersebut termasuk pada ibu hamil yaitu memberikan makanan tambahan pada ibu hamil, guna mencegah kekurangan energy dan protein kronis, mengurangi kekurangan zat besi dan asam folat, mengatasi kekurangan iodium, menanggulangi kecacingan pada ibu hamil. Intervensi untuk ibu menyusui dan anak 0-6 bulan adalah mendorong IMD (inisiasi menyusui dini) dilakukan 1 jam setelah melahirkan guna memberikan kolostrum pada bayi, mendorong setiap ibu untuk memberikan ASI eksklusif (Kementerian Desa, Pembangunan Daerah Tertinggal, 2018).

Perilaku ibu dalam pemenuhan gizi pada seribu hari pertama kehidupan atau Golden Period dapat dilihat dari mulai perawatan selama masa kehamilan kemudian saat bayi lahir yaitu dengan melakukan Inisiasi Menyusu Dini (IMD) langsung setelah bayi lahir, memberikan ASI Eksklusif mulai bayi usia 0-6 bulan dilanjutkan pemberian makanan 
pendamping ASI (MP-ASI) setelah anak berusia 6 bulan dan tetap melanjutkan pemberian ASI sampai usia 2 tahun, menimbang bayi tiap bulan di Posyandu untuk dipantau tumbuh kembangnya, memberikan kapsul vitamin A dan imunisasi lengkap sesuai jadwal (Erna, 2017).

Hasil penelitian ini sejalan dengan penelitian sebelumnya di Kota Surakarta oleh Sundari (2018), ditemukan bahwa pemberian ASI eksklusif pada anak usia 1224 bulan berhubungan dengan kejadian stunting dengan nilai $p=0,031$. Hasil penelitian lain di kota Minahasa menyimpulkan bahwa riwayat pemberian ASI eksklusif memiliki hubungan yang signifikan dengan kejadian stunting. Kegunaan ASI sangat banyak terutama ASI sebagai sumber nutrisi utama pada bayi, meningkatkan daya tahan tubuh, menurunkan angka mortalitas, meningkatkan inteligensi pada anak, mengandung asam lemak yang cocok untuk tubuh bayi, mampu memenuhi semua kebutuhan nutrisi anak, dan lain-lain (Notoatmodjo, 2012).

Pemberian ASI eksklusif terutama 6 bulan pertama kehidupan anak dipercaya mampu mencegah berbagai jenis penyakit dan penyakit alergi. Hal ini berhubungan dengan kandungan antibody dalam kolostrum ASI. Kolostrum adalah ASI yang keluar pertama sampai hari ke empat, mengandung anti infeksi dan memiliki protein tinggi. Apabila bayi diberikan ASI eksklusif maka anak akan tumbuh sehat serta jarang sakit. Karena penyakit dapat menyebabkan gangguan pertumbuhan pada anak. Infeksi menyebabkan nafsu makan menurun, gangguan penyerapan nutrisi, kehilangan mikronutrien secara langsung. Penelitian lain menyebutkan bahwa penyakit infeksi dapat mempengaruhi stunting (Anisa, 2012).

\section{KESIMPULAN}

Implikasi

Dari hasil penelitian dan pembahasan didapatkan kesimpulan bahwa balita stunting yang mendapatkan ASI eksklusif sebesar 58\% dalam kategori terpenuhi (ASI eksklusif diberikan selama 6 bulan), dan yang tidak terpenuhi sebesar $42 \%$ di wilayah kerja Puskesmas Kalibawang. Meskipun lebih banyak balita stunting yang diberikan ASI eksklusif artinya selain pemberian ASI eksklusif masih ada factor lain yang menyebabkan stunting seperti pemberian M-PASI, imunisasi, antenatal care, dan lain-lain. Jenis kelamin paling banyak perempuan sebesar $52 \%$ termasuk kategori stunting. Usia paling banyak usia $>36-60$ bulan sebesar $54 \%$.

\section{Keterbatasan}

Penelitian ini memiliki keterbatasan hanya mengumpulkan data melalui kuesioner tanpa disertai dengan wawancara alasan ibu tidak memberikan ASI eksklusif secara penuh agar hasil penelitian lebih komprehensif.

\section{DAFTAR PUSTAKA}

Adriani, M., \& Wirjatmadi, B. (2012). Pengantar Gizi Masyarakat. Jakarta: Kencana Prenada Media Group.

Aini, E. N., Nugraheni, S. A., \& Pradigdo, S. F. (2018). Faktor Yang Mempengaruhi Stunting Pada Balita Usia 24-59 Bulan di Puskesmas Cepu Kabupaten Blora. Kesehatan Masyarakat, 6(5), 454-461.

Anisa, P. (2012). Faktor-Faktor Yang Berhubungan Dengan Kejadian Stunsting Pada balita Usia 25-60 Bulan di Kelurahan Kalibaru Depok Tahun 2012. Universitas Indonesia.

Aridiyah, F. O., Rohmawati, N., \& Ririanty, M. (2015). Faktor-faktor yang Mempengaruhi Kejadian Stunting pada Anak Balita di Wilayah Pedesaan dan Perkotaan. Pustaka Kesehatan, 3(1), 163-170.

Badan Penelitian dan Pengembangan Kesehatan. (2018). Hasil Utama RISKESDAS 2018. Jakarta.

Dinas Kesehatan Daerah Istimewa Yogyakarta. (2017). Profil Kesehatan Daerah Istimewa Yogyakarta. Yogyakarta.

Emma, S., Jatmika, D., Indonesia, P. U., Kearney, A., Masyarakat, N., Meningkatkan, U., ... Dalam, H. (2015). Norma Masyakarat Untuk Meningkatkan Niat Ibu Hamil Dalam 
Memberikan ASI Eksklusif. Jurnal Kesehatan Samodra Ilmu, 6(1), 5057.

Eveline PN, \& Djamaludin, N. (2010). Panduan Pintar Merawat Bayi dan Balita. Jakarta: Wahyu Media.

Fahriani, R., Rohsiswatmo, R., \& Hendarto, A. (2014). Faktor yang Memengaruhi Pemberian ASI Eksklusif pada Bayi Cukup Bulan yang Dilakukan Inisiasi Menyusu Dini (IMD). Sari Pediatri, 15(6), 394-402.

Fitri, D. I., Chundrayetti, E., \& Semiarty, R. (2014). Artikel Penelitian Hubungan Pemberian ASI dengan Tumbuh Kembang Bayi Umur 6 Bulan di Puskesmas Nanggalo. Jurnal Kesehatan Andalas, 3(2), 136-140.

Illahi, R. K. (2017). Hubungan Pendapatan Keluarga, Berat Lahir, dan Panjang Lahir dengan Kejadian Stunting Balita 24-59 Bulan di Bangkalan. Jurnal Manajemen Kesehatan, 3(1), 1-14.

Kementerian Desa, Pembangunan Daerah Tertinggal, dan T. (2018). Buku Saku Desa dalam Penanganan Stunting (1st ed.). Jakarta: Kementerian Desa, Pembangunan Daerah tertinggal, dan Transmigrasi.

Kementerian Kesehatan Republik Indonesia Direktorat. (2018). Cegah Stunting itu Penting (No. 2). Stunting. Jakarta.

Kodrat, L. (2010). Dahsyatnya ASI \& Laktasi. Yogyakarta: Media Baca.

Lestari, W., Margawati, A., \& Rahfiludin, M. Z. (2014). Faktor Risiko Stunting pada Anak Umur 6-24 Bulan di Kecamatan Penanggalan Kota Subulussalam Provinsi Aceh. Jurnal Gizi Indonesia, 3(1), 37-45.

Marmi. (2012). Asuhan Kebidanan Pada Persalinan. Yogyakarta: Pustaka Pelajar.

Mitra. (2015). Permasalahan Anak Pendek (Stunting) dan Intervensi untuk Mencegah Terjadinya Stunting (Suatu Kajian Kepustakaan) Stunting Problems and Interventions to Prevent Stunting (A Literature Review). Jurnal Kesehatan Komunitas, 2(5), 254-261.

Notoatmodjo, S. (2012). Promosi Kesehatan dan Perilaku Kesehatan (1st ed.). Jakarta: Rineka Cipta.

Oktarina, Z., \& Sudiarti, T. (2013). Faktor

Risiko Stunting Pada Balita (24-59

Bulan) di Sumatera. Jurnal Gizi Dan Pangan, 8(3), 175-180.

Sundari, R. M. (2018). Hubungan Berat Badan Lahir Rendah (BBLR) dan Perilaku Pemberian ASI Eksklusif Dengan Kejadian Stunting Baduta di Puskesmas SAngkrah Kota Surakarta. Universitas Muhammadiyah Surakarta.

Unicef South Asia. (2017). Stop Stunting in South Asia. Kathmandu.

Walyani, E. S. (2015). Perawatan Kehamilan \& Menyusui Anak Pertama Agar Bayi Lahir dan Tumbuh Sehat. Yogyakarta: Pustaka Baru Press.

World Health Organization. (2018). World Health Statistics 2018 (Monitoring Helath For The SDGs). Geneva. 